International Journal of Language Education

Volume 5, Number 2, 2021, pp. 74-88

ISSN: 2548-8457 (Print) 2548-8465 (Online)

Doi: https://doi.org/10.26858/ijole.v5i2.15241

\title{
Students' Grammatical Errors in Essay Writing: A Pedagogical Grammar Reflection
}

\author{
Fitrawati \\ Universitas Negeri Padang, Indonesia \\ Email: fitra_bing@fbs.unp.ac.id \\ Dian Safitri \\ Universitas Negeri Padang, Indonesia \\ Email: diansafitri@fbs.unp.ac.id
}

Received: 20 November 2020

Reviewed: 3 January 2021-3 March 2021

Accepted: 13 April 2021

\begin{abstract}
Students of English as a Foreign Language (EFL) are expected to master the fundamental of grammar so they can produce good essays. However, despite having learned English at the secondary or university level, students tend to make many grammatical errors in their writing. This study presents the grammatical errors made by college EFL students in their essays and the pedagogical implications viewed from those errors. This is descriptive research with 30 second-year students who enrolled in an Essay Writing class as participants. Thirty written essays produced by the students were analyzed for grammatical errors. The findings revealed that there were 368 grammatical errors found in the students' essays. The most common one was in verb use (48\%). If teachers do not assist students to comprehend the concept of parts of speech, and essential and nonessential clauses, these students will continue to make errors in their more advanced writing. The findings may have useful pedagogical implications for English language teachers, syllabus designers, and test developers. Understanding students' difficulties and providing appropriate grammar instructions are the keys to teach grammar.
\end{abstract}

Keywords: grammatical errors, pedagogical implications, English writing competence

\section{Introduction}

Grammatical error is one of the problems faced by students in writing. Previous studies strongly recommend that the most beneficial approach of facilitating learners' command of grammar in writing is to employ students' writing as the starting point for discussing grammatical concepts (Calkins, 1980; DiStefano \& Killion, 1984; Harris, 1962 in Hanganu, 2015). Teachers can facilitate grammar instruction that directs students in their efforts to recognize and correct errors in usage (Chin, 2000). The teacher who sees that many students are writing sentences containing misplaced modifiers can present a mini-lesson on this concept, using examples from student writing. The teacher can instruct the students to exchange their drafts with their peers for editing purposes. Integrating grammar instruction into the revising and editing process assists 
students in making immediate applications. Thus, it allows them to see the relevance of grammar to their own writing (Chin, 2000).

As Bram (2002:1) states, problems which are faced by EFL students in composing written texts are in deciding verb forms, appropriate articles, prepositions, punctuations, countable and uncountable nouns, subject and verb agreement, and spelling. Besides, Ferris (2011:149) suggests that wrong word choice and sentence structure errors are common issues in students' writing. In addition, Chen (2002:74) found that there are some types of students' writing problems. They are word choice, tenses, word usage, definite articles, relative clauses, redundancy, spelling and punctuations, and sentence level problem.

Considering those problems, this research focuses on analyzing students' grammatical errors in writing a text. This study aims to reveal the grammatical errors in essays written by second year-students who enrolled essay writing examination. Furthermore, the writers would like to know various forms of errors in part of speech use there. Finally, this study intends to find out the pedagogical implication of errors made by the students in their writings. To reach the purpose of this research, these are the questions to answer:

(1) What are the types of grammatical errors committed by EFL students in essay writing?

(2) What are the pedagogical implications viewed from the errors made by EFL students?

\section{Literature review}

Error analysis

Error Analysis (EA) is an approach of linguistic study that focuses on the errors learners make and it assists educators in understanding the language learning process. Since various errors are seen as a means to an end, some researchers tend to discover the appropriate corrective techniques that can aid the effective learning and teaching of English. This is because through writing one can evaluate the language competency, capability to recall and capability to think. Darus Saadiyah and Subramaniam (2009) used Error Analysis (EA) to examine errors in a corpus of 72 essays written by 72 participants. Corder (1967, pp. 19-27) presents a completely different point of view by saying those errors are "important in and of themselves". In his opinion, systematic error analysis can enable teachers to determine the kind of reinforcement needed in teaching.

Furthermore, Wee, Sim \& Jusoff (2009) found overt teaching to reduce subject-verb agreement (SVA) errors of Malaysian EAP learners. The explanation of the rules of a new structure either through the deductive (direct) approach or through the inductive (discovery) approach has greatly benefitted the subjects. Besides that, Ruziah (2006) has enhanced the correct use of prepositions through error identification drill exercises among the 17 KPLI (M) students. Even though both findings showed positive outcomes, they are only applicable for certain aspects that are on SVA and prepositions in writing. According to Corpuz (2011), the error correction technique in writing benefits teachers in creating awareness among learners, in instilling independent reading habits among students besides aiding revision. Teachers can also gain benefits in designing or planning strategies and measures to help students overcome their problems and improve their language performance (Muhari \& Mansor, 2008). Myles (2002) also mentions that feedback is the most significant part of writing and that improvement is impossible without it. Indirectly, these will be able to inculcate awareness among the students of the common types of errors to avoid (Naeini, 2008). 
Pedagogical grammar

Pedagogical grammar can be viewed as the version of grammar that seeks to find, frame, and describe criteria for language education and rules of language use. It helps to identify optimal ways for teaching and learning the L2 language in a classroom (Ellis, 2006; Westney, 1994). L2 pedagogical grammar is an area of controversy (Ellis, 2002) because grammar has footings in linguistic theory, learning psychology, and language pedagogy. The notion 'grammar' has been varyingly and controversially defined (Hartwell, 1985). Francis (1954, p. 299-300) distinguished three grammar paradigms. Then, other researches (Clahsen \& Muysken, 1986; Hawkins, 2002; Schachter, 1988) focus on learning not teaching grammar. With the advent of the sociolinguistics enterprise in the late 1960s and systemic linguistics (Halliday, 1973), the role of grammar teaching was downplayed (Male, 2011) due to the vogue of the communicative approach to language under the newly growing fields. Unlike Chomsky, Krashen (1981) proposes an input-based model, yet (like Chomsky) highlighted learning rather than teaching grammar. Bresnan (1982) proposes the lexical-functional model to grammar that balances form and function, stresses their indispensability, and emphasizes that grammar input should be interactional.

\section{Research method}

Research design

This paper is a descriptive study that explicitly describes the grammatical errors committed by EFL students are and their pedagogical implication to EFL teachers, syllabus designers, and test developers. According to Gay (2009), the descriptive method involves collecting data to answer the questions concerning the current status of the subject of the study. Furthermore, according to Gall et.al (2007), the descriptive method involves making a careful description of educational phenomena.

\section{Research instrument and data collection}

The instrument of this research was a test. It was administered to 30-second year-students who enrolled in an Essay Writing class in the English Department of Universitas Negeri Padang Indonesia, in a natural situation-essay writing examination. The data of this study were the essays written by the students. To get them, they were instructed to compose an essay consisting of at least 300 words. The essay could be in narrative, explanation, hortatory exposition, analytical exposition, discussion, or review, under a free theme.

\section{Data analysis}

The data were manually analyzed to reveal a detailed error that cannot be detected by grammar checking applications. They were checked per essay in detail for grammatical errors. The errors were categorized into eight domains including verbs, nouns, prepositions, pronouns, adverbs, determiners, adjectives, and conjunctions. Those were counted for their frequency percentage and interpreted by using the Seven Likert Scale of Quality as follows:

\begin{tabular}{ll} 
Table 1. Quality Interpretation of Error Frequency Percentage \\
\hline Error Frequency Percentage (\%) & Interpretation \\
\hline 0 & Exceptional \\
\hline $1-10$ & Excellent \\
\hline
\end{tabular}




\begin{tabular}{ll}
\hline $11-25$ & very good \\
\hline $26-40$ & Good \\
\hline $41-55$ & Fair \\
\hline $56-80$ & Poor \\
\hline $81-100$ & Very poor \\
\hline
\end{tabular}

\section{Results}

The grammatical errors committed by EFL students in essay writing

Below is the analysis result in form of the number of errors committed by the students based on the error types.

Table 2. The Frequency and Interpretation of Grammatical Errors Made by EFL Students in Writing Essay

\begin{tabular}{llllll}
\hline No. & Type of Error & Frequency & $\begin{array}{l}\text { Percentage } \\
(\%)\end{array}$ & $\begin{array}{l}\text { Percentage After Rounded } \\
(\%)\end{array}$ & Interpretation \\
\hline 1 & Verbs & 178 & 48.36956522 & 48 & Fair \\
2 & Nouns & 44 & 11.95652174 & 12 & Very Good \\
3 & Pronouns & 28 & 7.608695652 & 8 & Excellent \\
4 & Adjectives & 19 & 5.163043478 & 5 & Excellent \\
5 & Determiners & 29 & 7.880434783 & 8 & Excellent \\
6 & Adverbials & 21 & 5.706521739 & 6 & Excellent \\
7 & Prepositions & 31 & 8.423913043 & 8 & Excellent \\
8 & Conjunctions & 18 & 4.891304348 & 5 & Excellent \\
\hline Total & & 368 & 100 & 100 & \\
\hline
\end{tabular}

From table 2, it can be seen that the most frequent grammatical error was in verb use as it existed 178 times or $48 \%$ in the students' essays. If it is referred to the interpretation, it can be said that the students have the fair ability in applying verb use in writing their essays. Meanwhile, the table also presents the sequence of the rest types of error which were not significantly different in which the range was about $5 \%$ to $8 \%$. Errors in prepositions, determiners, and pronouns have the same percentage. However, prepositions whose frequency 31 is the largest one among them, continued by determiners whose frequency 29 and pronouns whose frequency 28. Adjectives and conjunctions were also the same in percentage as $5 \%$, one point below adverbial whose percentage $6 \%$. Therefore, if they are interpreted, it can be said that the students are excellent in using appropriate pronouns, determiners, prepositions, adverbials, adjectives, and conjunctions in writing their essays.

\section{A grammatical error in verbs}

Among all indicated grammatical errors, verb use is the most common prevailing error of the students in their essay writing. However, the interpretation still falls within the fair category. It means that the students have enough abilities in using appropriate verbs in writing their essays.

Error in the verb is the wrong choice of word forms that indicate an action. It can be an error in form of subject-verb agreement and regular and irregular verbs. Below is the analysis result of verb use.

Table 3. The Distribution of Grammatical Error in Verb Use

\begin{tabular}{lllll}
\hline Type of Error & $\mathrm{Vs}$ & $\mathrm{Vi}$ & $\mathrm{Vr}$ & Total \\
\hline
\end{tabular}




\begin{tabular}{llclc}
\hline Total & 150 & 16 & 12 & 178 \\
Percentage (\%) & 84 & 9 & 7 & 100 \\
Interpretation & \multicolumn{2}{l}{ Very poorExcellent } & Excellent & \\
\hline
\end{tabular}

Note:

Vs=Subject-Verb Agreement

$\mathrm{Vi}=$ Irregular Verbs

$\mathrm{Vr}=$ Regular Verbs

Based on table 3, the error in the subject-verb agreement is the most error made by the students. There are 150 of 178 errors committed in this type, suggesting the students' dilemma in forming the sentences correctly. The frequency percentage of error in this type was $84 \%$ which means that the students were very poor in using appropriate verbs for their essays. The majority of the students faced problems in agreement, as they could not make subject and verbs agree because the verbs do not follow their subject closely and the number of subjects is unclear. It can be seen in the examples below:

Table 4. Example of Grammatical Error in Subject-Verb Agreement Made by EFL Students in Writing Essay

\begin{tabular}{lll}
\hline Student & Error & Correction \\
\hline Student 10 & The people were talking about the woman. & $\begin{array}{l}\text { The people were talking about the } \\
\text { woman. }\end{array}$ \\
Student 13 & $\begin{array}{l}\text { The government is good enough at managing } \\
\text { education. }\end{array}$ & $\begin{array}{l}\text { The government is good enough at } \\
\text { managing education. }\end{array}$ \\
\hline
\end{tabular}

Table 4 shows that some students were not able to apply the use of grammar rule properly that if the subject is singular then the verb is also singular, and when the subject is plural then also the verb must be in plural form. See the error did by Student 10. People is the plural subject, but the student used was as the auxiliary verb which is actually for the third singular subject. The same case was also made by Student 13. She might think that government is plural since it consists of many people, so she used are as its auxiliary verb which caused there is no agreement between the subject and the verb.

Regarding verb form, table 3 presents that only $9 \%$ error for regular and $7 \%$ error for irregular found in the student's essays. Those data means that the students were excellent in using the appropriate verb form in writing their essays. Below are examples of the errors.

Table 5. Example of Grammatical Error in Regular and Irregular Verbs Made by EFL Students in Writing Essay

\begin{tabular}{lll}
\hline Student & Error & Correction \\
\hline Student 5 & Yesterday, I receive a letter from my old friend,Yesterday, I received a letter from my old friend, \\
& Gina. & Gina. \\
Student 11 & They swim there two days ago. & They swam there two days ago. \\
\hline
\end{tabular}

Based on table 5, Student 5 failed to form a simple past sentence that should use the past verb in his sentence. He wrote receive which is a present verb in regular form instead of received which is the past form of it. Regarding irregular verbs, Student 11 wrote swim instead of swam. He presented a past event that requires past verb use. Swim belongs to an irregular verb that should swim when it is used in a simple past sentence. 
A grammatical error in nouns

Based on the result of data analysis, table 6 shows that noun use is the second most found in students' essay writing. There were 44 errors or $12 \%$ errors in this type made by the students. The table below shows the distribution of errors in nouns.

Table 6. The Distribution of Grammatical Error in Noun Use

\begin{tabular}{llllll}
\hline Type of Error & Nsg & Npl & Nct & Nuc & Total \\
\hline Total & 11 & 25 & 0 & 8 & 44 \\
Percentage & $25 \%$ & $57 \%$ & 0 & $18 \%$ & $100 \%$ \\
Interpretation & Very good & Poor & Exceptional & Very good & \\
\hline
\end{tabular}

Note:

Nsg: Singular Nouns

Npl: Plural Nouns

Nct: Countable Nouns

Nuc: Uncountable Nouns

From table 6, it can be seen that error in plural nouns is the most commonly found in the students' essays. Its frequency is 25 or $57 \%$ which means more than half of the whole errors in nouns. Therefore, it is interpreted by poor category which means that the students were poor in applying the rule plural noun use in their writing. It is followed by an error in singular nouns whose frequency 11 or $25 \%$ which is exactly one-fourth of the whole errors in nouns. This number falls within the very good category which means that the students were very good at using singular nouns for their essays. The same interpretation comes to an error in uncountable nouns. This error type was found eight times or $18 \%$ in the students' essays. However, in the scope of error in nouns, the students presented an outstanding performance on their writing that no error found in the case of countable nouns in their essays.

Table 7. Example of Grammatical Error in Nouns Made by EFL Students in Writing Essay

\begin{tabular}{|c|c|c|}
\hline Student & Error & Correction \\
\hline Student 1 & $\begin{array}{l}\text { There was } a \text { men walking behind the } \\
\text { woman. }\end{array}$ & $\begin{array}{l}\text { There was a man walking behind the } \\
\text { woman. }\end{array}$ \\
\hline Student 3 & $\begin{array}{l}\text { He could not use his two foots to } \\
\text { walk. }\end{array}$ & He could not use his two feet to walk. \\
\hline Student 18 & $\begin{array}{l}\text { The government has imported many } \\
\text { rices from Thailand. }\end{array}$ & $\begin{array}{l}\text { The government has imported much rice } \\
\text { from Thailand. }\end{array}$ \\
\hline
\end{tabular}

Table 7 shows the examples of students' errors in nouns. Student 1 made error in indicating singular noun. He wrote $a$ men instead of $a$ man. $A$ is an article which precedes a singular noun. Therefore, the phrase should be a man since men belongs to plural noun. The error could be caused by the similarity in pronunciation between the word man $/ \mathrm{mæn} /$ and men $/ \mathrm{men} /$.

The table presents an error made by Student 3 which is about forming plural noun. She wrote two foots instead of two feet. The word two which indicates plural should be followed by plural noun. She might have no knowledge about the plural form of foot, so she just added $-\mathrm{s}$ after it, so it became foots. The right plural form of foot is feet.

The third row of the table shows an error made by the student 18 in indicating uncountable noun. She wrote many rices instead of much rice. Rice belongs to uncountable noun which cannot be added by $-\mathrm{s}$ to form it plural but there is no change in its word. All uncountable nouns, including 
rice, have same form both in singular and plural form. In addition, uncountable nouns should not be preceded by quantifier many which should actually precede a countable noun. In this case, rice should be preceded by much as its appropriate quantifier.

Grammatical error in prepositions

The errors committed by the students in using prepositions are the inappropriate using of a word, such as in, from and to, that are used before a noun or pronoun to show place, position, time or method. Based on table 2, they show there are 31 errors or $8 \%$ error in prepositions found in the students' essays. The interpretation falls within excellent which means that the students were excellent in using preposition for their essays. It can be seen from these examples:

Table 8. Example of Grammatical Error in Preposition Made by EFL Students in Writing Essay

\begin{tabular}{lll}
\hline Student & Error & Correction \\
\hline Student 2 & No one could not account to the accident. & No one could not account for the accident. \\
\hline Student 12 & The room is on the river. & The room is by the river. \\
\hline
\end{tabular}

It can be seen that the students just randomly chose the preposition to be written. As what student 2 wrote account to instead of account for, and students 12 who wrote on the river instead of by the river. They did those errors which they thought right as they might be influenced by the common word used in their native language, Bahasa Indonesia.

Grammatical error in pronouns

Pronoun errors were found 28 times in the students' essays. In other word, they take 8\% from all errors made by EFL students in writing their essays. Pronoun includes personal pronouns, possessive pronouns, reflexive pronouns, demonstrative pronouns, interrogative pronouns, relative pronouns, indefinite pronouns and reciprocal pronouns. The error frequency distribution can be seen in the table below.

Table 9. The Distribution of Grammatical Error in Pronouns

\begin{tabular}{llllllllll}
\hline Type of Error & $\operatorname{Pr}$ & Ps & Rf & D & It & Rl & In & Rc & Total \\
\hline Total & 5 & 7 & 0 & 2 & 0 & 11 & 3 & 0 & 28 \\
Percentage & $18 \%$ & $25 \%$ & 0 & $7 \%$ & 0 & $39 \%$ & $11 \%$ & 0 & $100 \%$ \\
Interpretation & Very good & Very good & Exceptional & ExcellentExceptional & Good & Very good & exceptional & \\
\hline
\end{tabular}

Note:

$\operatorname{Pr}=$ Personal pronouns

Ps $=$ Possessive pronouns

$\mathrm{Rf}=$ Reflexive pronouns

$\mathrm{D}=$ Demonstrative pronouns

$\mathrm{It}=$ Interrogative pronouns

$\mathrm{Rl}=$ Relative pronouns

$\mathrm{In}=$ Indefinite pronouns

$\mathrm{Rc}=$ Reciprocal pronouns

Based on table 9, specifically, the students mostly made the errors in relative pronouns use since it was found 11 errors or $39 \%$ of the whole pronoun errors found in the students' essays. However, its interpretation still falls as good. Possessive pronouns take $25 \%$ of the whole errors in pronouns which is interpreted as very good. In addition, the same interpretation also goes to 
personal pronouns for $18 \%$ and indefinite pronouns by $11 \%$. Regarding demonstrative pronouns, they take $7 \%$ of all pronoun errors which is interpreted as excellent. On the contrary, the researchers find no error committed by the students in reflexive pronouns, interrogative pronouns and reciprocal pronouns. The table below shows the example of those errors.

\begin{tabular}{|c|c|c|}
\hline Student & Error & Correction \\
\hline Student 4 & I hope I can see they on holiday soon. & I hope I can see them on holiday soon. \\
\hline Student 7 & $\begin{array}{l}\text { The big house there is actually her, but he } \\
\text { has sold it and brings the money away. }\end{array}$ & $\begin{array}{l}\text { The big house there is actually hers, but he } \\
\text { has sold it and brings the money away. }\end{array}$ \\
\hline Student 8 & $\begin{array}{l}\text { When I went to a bookstore, I found there } \\
\text { were so many interesting books. That } \\
\text { books so amazed me. }\end{array}$ & $\begin{array}{l}\text { When I went to a bookstore, I found there } \\
\text { were so many interesting books. Those books } \\
\text { so amazed me. }\end{array}$ \\
\hline Student 13 & $\begin{array}{l}\text { When graduation time comes, it means } \\
\text { that we should leave the university which } \\
\text { we study many things with our friends } \\
\text { and lecturers. }\end{array}$ & $\begin{array}{l}\text { When graduation time comes, it means that } \\
\text { we should leave the university where we } \\
\text { study many things with our friends and } \\
\text { lecturers. }\end{array}$ \\
\hline Student 20 & $\begin{array}{l}\text { Neither of the lecturers are available for } \\
\text { the meeting. }\end{array}$ & $\begin{array}{l}\text { Neither of the lecturers is available for the } \\
\text { meeting. }\end{array}$ \\
\hline
\end{tabular}

Referring to table 10, Student 4 made an error in using personal pronouns. She wrote in her writing they instead of them. They is used when it is in subject position, but in her writing, they is placed in object position which should be them. Student 7 made an error in possessive pronoun. He wrote her to tell the readers the owner of the big house. Her actually belongs to possessive pronoun but it must be followed by the thing owned. If it is not, it should be hers. Relating demonstrative one, Student 8 made an error in this type of pronouns. He wrote that books instead of those books. The word books is plural, so the demonstrative word to point them should be in plural also, that is those. Furthermore, Student 13 made an error in relative pronouns. She wrote the university which instead of the university where to relate university, which means a place, to the next clause. The last kind of pronoun error is about indefinite pronouns performed by Student 20. He wrote neither of the lecturers are instead of neither of the lecturers is. Even the word lecturers is plural, in his sentence, it acts as collective noun. So if it is preceded by an indefinite pronoun neither in this case, it agrees with singular verb. Finally, it can be seen that the students were not able to choose the correct pronouns in their writing because of their confusion and carelessness in linking to the referred word(s).

Grammatical error in adverbs

Based on the analysis result, errors in adverbs account for $6 \%$ of students' errors in their essay writing or they were found 21 times there. The interpretation of this error type falls within excellent. Below are the examples of the adverb errors found in the students' essays.

Table 11. Example of Grammatical Error in Adverbs Made by EFL Students in Writing Essay

\begin{tabular}{lll}
\hline Student & Error & Correction \\
\hline Student 10 & $\begin{array}{l}\text { The government has worked so hardly to } \\
\text { cut the distribution of drug among the } \\
\text { students. }\end{array}$ & $\begin{array}{l}\text { The government has worked so hard } \\
\text { to cut the distribution of drug among } \\
\text { the students. }\end{array}$ \\
\hline
\end{tabular}




\begin{tabular}{lll}
\hline Student 5 & $\begin{array}{l}\text { The time run too fastly so they could not } \\
\text { finish their work. }\end{array}$ & $\begin{array}{l}\text { The time run too fast so they could not } \\
\text { finish their work. }\end{array}$ \\
\hline
\end{tabular}

Table 11 shows that Student 21 and Student 22 made the same error in using adverb of manner. Student 21 wrote hardly instead of hard, and Student 22 wrote fastly instead of fast. In using the word hard and fast as adverb of manner, they must be in their adjective form or have no change. They must not be added by $-l y$ at the end of the word. The examples present the confusion of the students in forming adverb of manner. They actually have got the material about adverbs since in their first semester of university study, but they seemed still confused to apply it correctly.

Grammatical error in determiners

$8 \%$ of errors were of this type. It is interpreted as excellent which means that the students are excellent in using determiners for their essays. There are two kinds of error in determining determiners, they are articles and quantifiers. The table below shows the distribution of the error:

Table 12. The Distribution of Grammatical Error in Determiners

\begin{tabular}{llll}
\hline Type of Error & Art. & Q & Total \\
\hline Total & 26 & 3 & 29 \\
Percentage & $90 \%$ & $10 \%$ & $100 \%$ \\
Interpretation & Very poor & Excellent & \\
\hline
\end{tabular}

Note:

Art. : : Articles

Q : Quantifiers

Table 12 presents the analysis result of error in determiners. It shows that errors in articles were found mostly for 26 times or $90 \%$ of all errors in pronouns. It means that the students were very poor in using appropriate articles in writing their essays. In other hand, the rest for only $10 \%$ was the errors found in quantifiers which means that the students were excellent in using quantifier. Below are the examples of the students' errors in determiners.

Table 13. Example of Grammatical Error in Determiners Made by EFL Students in Writing Essay

\begin{tabular}{lll}
\hline Student & Error & Correction \\
\hline Student 23 & $\begin{array}{l}\text { She was such crying when she pointed at } \\
\text { house. }\end{array}$ & $\begin{array}{l}\text { She was such crying when she pointed } \\
\text { at the house. }\end{array}$ \\
Student 25 & $\begin{array}{l}\text { Much people attended the night festival } \\
\text { which was held by the government of } \\
\text { Padang. }\end{array}$ & $\begin{array}{l}\text { Manich was held by the government of } \\
\text { Padang. }\end{array}$ \\
\hline
\end{tabular}

Error in using articles can be seen in Student 23. He wrote pointed at house instead of pointed at the house. The should be added to determine house. Concerning error in deciding quantifiers, it can be seen in Student 25 writing where he wrote much instead of many. It was considered error since people is countable while much is used to precede an uncountable noun.

Grammatical error in adjectives

Few students made error in adjectives. This type takes only $5 \%$ of all errors or was found for 19 times in the students' essays. It can be said that the students are excellent in using adjectives in writing their essays. The examples can be seen in the table below: 
Table 14. Example of Grammatical Error in Adjectives Made by EFL Students in Writing Essay

\begin{tabular}{lll}
\hline Student & Error & Correction \\
\hline Student 29 & $\begin{array}{l}\text { The today's weather is more bad } \\
\text { than it of yesterday. }\end{array}$ & $\begin{array}{l}\text { The today's weather is worse than it of } \\
\text { yesterday. }\end{array}$ \\
$\begin{array}{ll}\text { He looked like a confuse man } \\
\text { when he lost his wallet. }\end{array}$ & $\begin{array}{l}\text { He looked like } \text { a confused man when he } \\
\text { lost his wallet. }\end{array}$ \\
\hline
\end{tabular}

From the table above, it can be seen that the students 29 was got confused in determining comparative form of the word bad. He wrote more bad instead of worse. He thought that bad can be preceded by the word more to express a comparison like most adjectives which are more than two syllables. This error also demonstrates that the students were influenced by their native language, Bahasa Indonesia in forming a sentence. In addition, Student 30 made an error in deciding adjective which explains the object. He wrote a confuse man instead of a confused man. Here, confused is the right adjective which explains man.

Grammatical error in conjunctions

There are three kinds of conjunctions. They are coordinating conjunctions, correlative conjunctions and subordinating conjunctions. From all data, errors in conjunctions take the smallest number, same with adjective error frequency percentage, that is only $5 \%$ of all errors committed by the students in writing their essays. The difference was on their frequency. Errors in conjunction were found 18 times, a point below those of adjectives. The number can be interpreted that the students are excellent in using conjunctions for their essays. The distribution can be seen in the following table.

Table 15. The Distribution of Grammatical Error in Conjunctions

\begin{tabular}{lllll}
\hline Type of Error & Coor. & Corre. & Sub. & Total \\
\hline Total & 9 & 6 & 3 & 18 \\
Percentage & $50 \%$ & $33 \%$ & $17 \%$ & $100 \%$ \\
Interpretation & Fair & Good & Very good & \\
\hline
\end{tabular}

Note:

Coor : Coordinating Conjunctions

Corre : Correlative Conjunctions

Sub. : Subordinating Conjunctions

It was shown by table 15 that there were not many students made errors in using conjunctions in their writing. Errors in coordinating conjunctions were found 9 times or 50\%, a half of all errors in conjunctions. It can be interpreted that the students have fair ability in using coordinating conjunctions. The errors in correlative conjunctions were 6 times found or $33 \%$ of all errors in conjunctions. It can be said that the students are good in using correlative conjunctions in writing their essays. Meanwhile, only 3 errors found in subordinating conjunction type or $17 \%$ of all conjunction errors. The interpretation falls within very good. The examples can be seen in the table below.

Table 16. Example of Grammatical Error in Conjunctions Made by EFL Students in Writing Essay

Student Error Correction




\begin{tabular}{|c|c|c|}
\hline Student 15 & $\begin{array}{l}\text { My two favorite subjects when I was at } \\
\text { Senior High School were English or Math. }\end{array}$ & $\begin{array}{l}\text { My two favorite subjects when I was at } \\
\text { Senior High School were English and Math. }\end{array}$ \\
\hline Student 19 & $\begin{array}{l}\text { Padang is neither hot or cold, so it is an } \\
\text { ideal city to live in. }\end{array}$ & $\begin{array}{l}\text { Padang is neither hot nor cold, so it is an } \\
\text { ideal city to live in. }\end{array}$ \\
\hline Student 24 & $\begin{array}{l}\text { When Jakarta flooded, the people spent all } \\
\text { day cleaning up their houses and } \\
\text { surroundings helped by many volunteers. }\end{array}$ & $\begin{array}{l}\text { After Jakarta flooded, the people spent all } \\
\text { day cleaning up their houses and } \\
\text { surroundings helped by many volunteers. }\end{array}$ \\
\hline
\end{tabular}

Referring to table 16, Student 15 made an error in using coordinating conjunctions in writing English or Math instead of English and Maths. It is considered an error since she wrote my two favorite subjects. The phrase indicates an addition, not an option, so it should be and. Furthermore, Student 19 made an error in using correlative conjunctions in writing neither hot nor cold instead of neither hot nor cold. Neither and nor are used together to link two words to express a negative statement. Meanwhile, Student 24 made an error in using a subordinating conjunction. She wrote When Jakarta flooded, ... instead of After Jakarta flooded, .... It is considered as an error because the following clause the people spent all day cleaning up their houses and surroundings helped by many volunteers indicates an action done after the flood. Therefore, the subordinating conjunction should be after.

\section{Discussion}

The pedagogical implication in this study was viewed from errors made by the students.

As presented in the data, the most frequent error made by the student errors in verbs. In most cases, errors in Verbs occurred from what Richards (1973) proposes as overgeneralization and ignorance of rule restrictions. This study can illuminate certain issues pertaining to how school teachers can help their students to produce better essay writing by understanding students' weaknesses in writing. Teachers can modify their teaching materials based on the students' needs or writing errors. The students made grammatical errors in their writing as they had inadequate grammatical knowledge. The results of this study suggest some ways for ESL teachers to enhance students' writing, specifically by providing some feedback after marking their essays and also making the students rewrite the essays after corrections. They also can apply peer evaluation in writing class to provide feedback. Myles (2002) states that feedback is the most significant part of writing and an improvement is impossible without it. Indirectly, these will be able to inculcate awareness among the students of the common types of errors to avoid (Naeini, 2008).

Teachers can integrate grammar instruction with writing instruction; they should use the grammar terms that make sense to the students (Chin, 2000). By incorporating grammar terms naturally into the processes of editing, revising, and proofreading, teachers can help students understand and apply grammar purposefully to their own writing. Strategies such as writing conferences, partnership writing, grammar mini-lessons, and peer response groups are all valuable methods for integrating grammar into writing instruction (Chin, 2000). Although this study was undertaken on a very small scale, the results of the study are quite significant. They show the possibility of teachers employing various strategies to assist students in applying grammatical concepts to achieve their writing purpose.

From the analysis of data, the followings are some pedagogical implications that can be drawn to explain the phenomena above.

Implications for EFL teachers

From the study of learners' errors, teachers can identify the problematic areas for learners 
at different levels of instruction. They will be able to infer the nature of the learner's knowledge of the target language at a given stage in their learning career and discover what they still have to learn. A course based on the frequency of errors will enable the teacher to teach at the point of error and to put more emphasis on those areas where the error frequency is higher. They should give more teaching and exercises repeatedly on those areas

Implications for syllabus designers

Errors are significant to syllabus designers to see what items are important to be included in the syllabus and what items are redundant and should be excluded. Error analysis can be used as a means for both assessing the student's learning in general and the degree of overlap between the learner's learning syllabus and that of the teachers. Therefore, in the syllabus, those eight types of grammatical errors made by the EFL students, including errors in verb, noun, pronoun, preposition, adjective, determiner, adverb, and conjunction should be primary topics that have to be designed in a longer period, so they get more time allocation. Those can also be placed in more than a section or inserted in other topics so they can be taught repeatedly. This way will make the students get a better understanding of them. It is in line with what Muhari \& Mansor (2008) explain that designing or planning strategies and measures can help students overcome their problems and improve their language performance.

Implications for test developers

Testing should be based on what has been taught and the test developers should be familiar with students' difficulties and errors. Test constructors can concentrate on parts of the teaching materials which are proved by error analysis to be more difficult for the students. Moreover, errors can form good distracters for test constructors, especially in multiple-choice items. The distracters of a multiple-choice test designed for eliciting data from second language learners should be selected from the common errors of the students. However, the present author believes that avoidance can be controlled to some extent by using certain elicitation techniques (e.g., direct translation from L1 into L2) which forces the learners to produce the grammatical structures or lexical items under investigation. Studies by Benson (2002); Cedar (2004); Chen \& Huang (2003); Collins (2002); Ghabool et al. (2012); Jarvis (2000) and Seyyed (2012) conclude that there is an impact or interference from their first language during the process of writing in English. Therefore, the writing test developers should consider the most suitable theme or topic which is familiar to the students and where the grammar rules which have been taught can be applied there. It is as what Chin (2000) says that teachers can integrate grammar instruction with writing instruction. Researchers agree that it is more effective to teach punctuation, sentence variety, and usage in the context of writing than to approach the topic by teaching isolated skills (Calkins, 1980; DiStefano \& Killion, 1984 and Harris, 1962 in Hanganu, 2015). When students revise and edit their writing, teachers can facilitate grammar instruction that directs students in their efforts to recognize and correct errors in usage (Chin, 2000).

Error correction and attitudes towards errors

Another pedagogical implication of error analysis is error correction and attitudes towards errors. Brooks (1960) in his then-famous book, Language and Language Learning, considers errors to have a relationship to learning resembling that of sin to virtue. He stated, "Like sin, the error is to be avoided and its influence overcome, but its presence is to be expected" (p. 58). Brooks suggests an instructional procedure that would help language learners produce error-free 
utterances: "The principal method of avoiding error in language learning is to observe and practice the right model at sufficient number of times; the principal way of overcoming it is to shorten the time lapse between the incorrect response and the presentation once more of the correct model" (p. 58). In other word, a fast response or correction are required to avoid more errors.

\section{Conclusion}

By noticing the research findings, it can be concluded that most of English department students of Universitas Negeri Padang generally are able to write a good writing but they still made some errors in parts of speech. The most common error made by the students was in verb use. In general, they also made errors in using nouns, pronouns, adjectives, determiners, adverbs, prepositions and conjunctions. It can be concluded that the students made the errors because of the factor of rules ignorance and confusion. It happens because they were not sure about the rule of grammar and their first language inference. Thus, they tended to approximate the rule of grammar even the words in their writing to ease their burden in writing an essay. Related to the research, there are some suggestions that can be given to the teachers as the implication of pedagogical grammar. They need to be more strategic in teaching grammar, i.e., by integrating grammar and writing instruction. Furthermore, they have to explain the rules of verb use more clearly and focus, provide extra lesson to the most problematic areas, give more exercise and pay more attention to students' writing by giving fast response in form of corrections to avoid more errors. Peer evaluation can also be applied in providing feedback to the students' writing.

Declaration of conflicting interest

The authors state that there is no conflict of interest concerning the publication of this article.

Funding acknowledgement

This research received no external funding.

\section{References}

Benson, C. (2002). Transfer/Cross-linguistic influence. ELT Journal, 56(1), 68-70. https://doi.org/10.1093/elt/56.1.68

Bram, B. (2002). Improving Writing Skills English Education Study Program Sanata Dharma University. Kanisius.

Bresnan, J. (1982). The mental representation of grammatical relations. Mit Pr.

Brooks, N. (1964). Language and language learning : theory and practice. Harcourt, Brace \& World.

Calkins, L. M. (1980). When children want to punctuate: basic skills belong in context. Language Art, 57(5).

Carter, R. (1997). Investigating English discourse : language, literacy and literature. Routledge.

Cedar, P. S. (2004). Transferability and translatability of idioms by Thai-speaking learners of English.

Chen, C. Y., \& Huang, H. Y. (2003). L2 Acquisition of Subject - Prominence by EFL Students in Taiwan. English Teaching \& Learning Journal, 27(4), 99-122.

Chen, Y. (2002). The problems of university EFL writing in Taiwan. Korea TESOL Journal, 5(1). Chin, B. A. (2000). The role of grammar in improving students'writing. Oxford.

Chomsky, N. (1986). Barriers. MIT Press.

Clahsen, H., \& Muysken, P. (1986). The availability of universal grammar to adult and child 
learners - a study of the acquisition of German word order. Interlanguage Studies Bulletin (Utrecht), 2(2), 93-119. https://doi.org/10.1177/026765838600200201

Corder, S. P. (1967). The Significance of Learner's Errors. Iral - International Review of Applied Linguistics in Language Teaching, 5(1-4). https://doi.org/10.1515/iral.1967.5.1-4.161

Corder, S. P. (1975). Error Analysis, Interlanguage and Second Language Acquisition. Language Teaching, 8(04), 201. https://doi.org/10.1017/s0261444800002822

Corpuz, V. A. F. (2011). Error correction in second language writing: Teachers'beliefs, practices, and students'preferences.

Darus, Saadiyah and Kaladevi Subramaniam. 2009. Error analysis of written essays of Secondary School studentss in Malaysia: A Case Study. European journal of social sciences, 8 (3)

DiStefano, P., \& Killion, J. (1984). Assessing Writing Skills through a Process Approach. English Education, 16(4), 203-207. https://www.jstor.org/stable/40172531

Ellis, R. (1994). The Study of Second Language Acquisition. Oxford University Press.

Ferris, D. (2011). Treatment of error in second language student writing. University Of Michigan Press.

Gall, M. D., Gall, J. P., \& Borg, W. R. (2007). Educational research : an introduction. Pearson/Allyn \& Bacon.

Ghabool, N., Mariadass, M. E. A., \& Kashef, S. H. (2012). Investigating Malaysian Esl Students' Writing Problems on Conventions, Punctuation, and Language Use at Secondary School Level. Journal of Studies in Education, 2(3). https://doi.org/10.5296/jse.v2i3.1892

Gay, L. R., Mills, G., \& Airasian, P. W. (2009). Educational Research: Competencies for Analysis and Applications. My Education Lab. Prentice Hall.

Halliday, M. A. K., \& Hasan, R. (1989). Language, context, and text: Aspects of language in a social-semiotic perspective. Oxford: Oxford University Press in Hyland, K. (2002). Teaching and researching writing. Longman.

Hanganu, E. C. (2015). Teaching Grammar in College.

Harris, R. J. (1962). An experimental inquiry into the functions and value of formal grammar in the teaching of written English to children aged twelve to fourteen. Unpublished doctoral's dissertation. University of London in Hanganu, Eduard. (2015). Teaching grammar in college. 10.13140/RG.2.1.2292.8806.

Hartwell, P. (1985). Grammar, Grammars, and the Teaching of Grammar. College English, 47(2), 105-127. https://doi.org/10.2307/376562

Hawkins, R. (2002). The theoretical significance of Universal Grammar in second language acquisition. Second Language Research, 17(4), 345-367. https://doi.org/10.1177/026765830101700404

James, C. (2001). Errors in language learning and use: Exploring error analysis. Foreign Language Teaching and Research Press.

Jarvis, D. (2000). The Process Writing Method. TESL Journal, 8(7).

Krashen, S. D. (1985). The input hypothesis: Issues and implications. Longman.

Male, H. (2011). Students' View on Grammar Teaching. JET (Journal of English Teaching), 1(1), 57. https://doi.org/10.33541/jet.v1i1.52

Mohtar, T. M. T., Kepol, N., Ahmad, A. Z. L, Singh, S. C. K, Yan, N., \& Mat, M. (2017). Validation of the scaffolding model and modules for teaching ESL writing skills in national schools in Malaysia

Muhari, Noraisah \& Mansor, Wan Fara Adlina Wan. (2008). An analysis of ESL students' multimedia project work: A case of language transfer 
Myles. (2002). Second language writing and research: The writing process and error analysis in student texts. TESL-EJ. http://tesl-ej.org/ej22/a1.html

Narinasamy, I., Mukundan, J., \& Nimehchisalem, V. (2013). The Use of Progressives among Malaysian ESL Learners. English Language Teaching, 6(11), 39-48. https://doi.org/10.5539/elt.v6n11p39

Richards, J. C. (1973). Error analysis. Longman.

Ruziah, M. Z. (2006). Enhancing the correct use of prepositions through error identification drill exercises among the KPLI (M) students. JURNAL IPBA, 3(3), 10-15.

Schachter, J. (1990). On the issue of completeness in second language acquisition. Interlanguage Studies Bulletin (Utrecht), 6(2), 93-124. https://doi.org/10.1177/026765839000600201

Shaughnessy, M. P. (1977). Errors and expectations : a guide for the teacher of basic writing. Oxford University Press.

Wee, R., \& Meranek, J. (2009). Sources of Errors: An Interplay of Interlingual Influence and Intralingual Factors. European Journal of Social Sciences, 11(2), 349-390.

Wee, R., Sim, J., \& Jussof, K. (2009). Enhancing the Quality of EAP Writing through Overt Teaching. English Language Teaching, 2(3), 56-68. https://doi.org/10.5539/elt.v2n3p58

Wee, R., Sim, J., \& Jusoff, K. (2010). Verb-form errors in EAP writing. Educational Research and Review, 5(1), 16-23.

Westney, P. (1994). Rules and pedagogical grammar. Perspectives on Pedagogical Grammar, 72 96. https://doi.org/10.1017/cbo9781139524605.006 